\title{
Excess weight loss in a patient with type 2 diabetes mellitus treated with an SGLT-2 inhibitor
}

\author{
Edyta Cichocka, Janusz Gumprecht
}

School of Medicine with the Division of Dentistry in Zabrze, Medical University of Silesia, Katowice, Poland, Department of Internal Medicine, Diabetology, and Nephrology

Key words: weight loss; diabetes; SGLT-2 inhibitor

\section{Case report}

A 62-year-old obese male patient with a 12-year history of type 2 diabetes was hospitalised in 2018 in the Department of Diabetes to optimise diabetes treatment. The patient had previously been treated with multiple injections of insulin (regular human insulin before meals and insulin glargine at night, daily dose of insulin = 140 IU) and metformin (3000 mg/day). Out-patient $\mathrm{HbA}_{1 \mathrm{c}}$ level was $12 \%$ (108 mmol/mol). Additionally, the medical history revealed dyslipidaemia and hepatic steatosis. The patient was in the process of getting divorced, which exposed him to additional stress. The patient did not follow the rules of healthy nutrition, meal consumption was irregular, and regular physical activity was not undertaken. The non-smoking patient who consumed 2-3 bottles of beer per week showed poor knowledge about diet and diabetes.

On admission, physical examination did not reveal any significant abnormality except for obesity (BMI $30 \mathrm{~kg} / \mathrm{m}^{2}$ ) and elevated blood pressure (160/100 mm Hg). Laboratory tests showed $\mathrm{HbA}_{1 \mathrm{c}}$ level
$12 \%$ (108 $\mathrm{mmol} / \mathrm{mol})$, mixed dyslipidaemia, and elevated liver function tests (ALT $68 \mathrm{U} / \mathrm{L}$, AspaAT $52 \mathrm{U} / \mathrm{L}$ ). The glycaemic profile is given in Table I.

The patient was instructed in terms of diet, the need to increase physical activity, and basic information related to diabetes. The subject was prescribed an antihypertensive drug (ramipril) and a statin (rosuvastatin). Diabetes treatment was modified: a full dose of metformin and insulin were maintained, and an SGLT-2 inhibitor was added (empagliflozin). A decrease in insulin requirement (from $140 \mathrm{IU}$ to $100 \mathrm{IU} /$ day) and an improvement in glycaemic control were observed during hospitalisation.

Six months later the patient was re-admitted. He had lost $21 \mathrm{~kg}$ of body weight (from $98 \mathrm{~kg}$ to $79 \mathrm{~kg}$ ). During that period, prandial insulin was gradually reduced and then discontinued (treatment of diabetes included metformin $3000 \mathrm{mg}$, empagliflozin $10 \mathrm{mg}$, insulin glargine $20 \mathrm{IU})$. Glycaemic control was good, and the $\mathrm{HbA}_{1 \mathrm{c}}$ level was $6.7 \%$ (50 $\left.\mathrm{mmol} / \mathrm{mol}\right)$. Due to low blood pressure the patient also discontinued the antihypertensive drug. There were no "self-reported"

Table I. Glucose measured using a glucometer

\begin{tabular}{|c|c|c|c|c|c|c|c|c|}
\hline \multirow[t]{2}{*}{ Date } & \multicolumn{7}{|c|}{ Glucose level [mg/dL] } & \multirow[b]{2}{*}{$\begin{array}{l}\text { At } 3 \text { a.m. } \\
{[\mathrm{mg} / \mathrm{dL}]}\end{array}$} \\
\hline & Fasting & $\begin{array}{c}2 \mathrm{~h} \text { after } \\
\text { breakfast }\end{array}$ & $\begin{array}{l}\text { Before } \\
\text { dinner }\end{array}$ & $\begin{array}{c}2 \mathrm{~h} \text { after } \\
\text { dinner }\end{array}$ & $\begin{array}{l}\text { Before } \\
\text { supper }\end{array}$ & $\begin{array}{c}2 \mathrm{~h} \text { after } \\
\text { supper }\end{array}$ & $\begin{array}{c}\text { Before } \\
\text { bedtime }\end{array}$ & \\
\hline 19 Feb 2018 & 386 & 419 & 267 & 232 & 262 & 232 & 189 & 192 \\
\hline 20 Feb 2018 & 349 & & 300 & & 258 & & 132 & 133 \\
\hline 21 Feb 2018 & 204 & & 210 & & 211 & & 133 & \\
\hline 22 Feb 2018 & 181 & & 183 & & 178 & & 92 & 149 \\
\hline 23 Feb 2018 & 137 & 157 & 111 & 132 & 123 & 156 & 111 & \\
\hline
\end{tabular}

Edyta Cichocka Ph.D., Katedra Chorób Wewnętrznych, Diabetologii i Nefrologii , Wydział Lekarski z Oddziałem Lekarsko-Dentystycznym w Zabrzu, Śląski Uniwersytet Medyczny w Katowicach, ul. 3 go Maja 13/15, 41-800 Zabrze, tel: (+48) 530 032 206; e-mail: sedyta@mp.pl 
Table II. Glucose measured using a glucometer

\begin{tabular}{|c|c|c|c|c|c|c|c|c|}
\hline \multirow[b]{2}{*}{ Date } & \multicolumn{7}{|c|}{ Glucose level [mg/dL] } & \multirow[b]{2}{*}{$\begin{array}{r}\text { At } 3 \text { a.m } \\
{[\mathrm{mg} / \mathrm{dL}]}\end{array}$} \\
\hline & Fasting & $\begin{array}{c}2 \mathrm{~h} \text { after } \\
\text { breakfast }\end{array}$ & $\begin{array}{l}\text { Before } \\
\text { dinner }\end{array}$ & $\begin{array}{c}2 \mathrm{~h} \text { after } \\
\text { dinner }\end{array}$ & $\begin{array}{l}\text { Before } \\
\text { supper }\end{array}$ & $\begin{array}{l}2 \mathrm{~h} \text { after } \\
\text { supper }\end{array}$ & $\begin{array}{c}\text { Before } \\
\text { bedtime }\end{array}$ & \\
\hline 15 0ct 2018 & 98 & 234 & 191 & 88 & 97 & & & \\
\hline 16 Oct 2018 & 103 & 237 & 139 & 93 & 138 & 112 & 163 & 110 \\
\hline 17 0ct 2018 & 112 & 127 & 127 & & 203 & & 186 & \\
\hline 18 0ct 2018 & 119 & 161 & 137 & & 132 & & 123 & \\
\hline 19 Oct 2018 & 111 & 127 & 111 & 132 & 123 & 156 & 111 & \\
\hline
\end{tabular}

changes in diet or physical activity in the patient. The subject regularly consumed beer. Physical examination did not reveal any abnormality. Laboratory tests showed improvement in the lipid profile and liver function. Glucose in the urine was detected.

Further diagnostic procedures were performed to detect or exclude cancer. The patient underwent urological examination (PSA $0.29 \mathrm{ng} / \mathrm{mL}$ ), thyroid dysfunction was excluded (TSH 1.16 IU/mL), CEA was negative, and gastroscopy revealed slight gastritis. Additionally, chest X-ray and contrast-enhanced abdominal CT did not reveal any abnormal findings. Further body weight reduction $(2.5 \mathrm{~kg} / 8$ days) was noted during hospitalisation. Daily diuresis was $\sim 1700 \mathrm{~mL}$ and the diet was balanced (with proper supply of calories). The glycaemic profile at the time of the second hospitalisation is given in Table II. Treatment of diabetes was modified: empagliflozin was discontinued, metformin was maintained, and insulin therapy was used in the basal plus regimen (insulin aspart 5 IU before breakfast, insulin glargine at night $20 \mathrm{IU})$. During the next examination in the Outpatient Diabetes Clinic, the patient presented with optimally regulated diabetes $\left(\mathrm{HbA}_{1 \mathrm{c}} 6.8 \%\right.$, without hypoglycaemia). No further weight loss was observed.

\section{Discussion}

Gliflozins are used at every stage of diabetes treatment [1]. The most important feature of these drugs is their beneficial effect on the reduction of cardiovascular risk. Their action is related to the inhibition of SGLT-2 in the proximal convoluted tubule to prevent reabsorption of glucose and sodium and facilitate its excretion in urine thereby promoting a decrease in blood pressure and glycosuria [2]. They also result in a decrease in body weight, which is associated with renal loss of glucose — as much as $80 \mathrm{~g} /$ day (320 kcal/day). Weight loss is the result of a caloric deficit caused by the elimination of glucose and higher renal water excretion (osmotic diuresis). SGLT-2 inhibitors reduced body weight by as much as $4.7 \mathrm{~kg}$ [3-4]. Body weight reduction using SGLT-2 inhibitors gradually slows down and becomes stable after 26-34 weeks [5].

In the presented patient, we observed excess weight loss and, above all, an improvement in glycaemic control that was associated with the use of empagliflozin. In our opinion, the progressive weight loss cannot be attributed to a change in lifestyle. However, other factors that contributed to high response to treatment should be considered: diuresis, water loss due to reduction in glycogen, and probably reduced calorie intake unnoticed by the patient [5].

The loss of $1 \mathrm{~kg}$ of body weight is equivalent to the loss of $7000 \mathrm{kcal}$. The patient lost $21 \mathrm{~kg}$ within about 180 days, which would mean the loss of 205 grams of glucose in urine daily $(820 \mathrm{kcal})$. That rate of urinary glucose excretion also exceeds generally accepted rates of efficacy of these drugs. But is it possible? Does it result from the hyper-reactivity of SGLT-2 or a mechanism of drug action that has not been discovered yet?

\section{References}

1. Diabetology C. 2018 Guidelines on the management of diabetic patients. A position of Diabetes Poland. Clin Diabet. 2018; 7(1): 1-90, doi: $10.5603 / \mathrm{dk} .2018 .0001$.

2. Chao EC. SGLT-2 Inhibitors: A New Mechanism for Glycemic Control. Clin Diabetes. 2014; 32(1): 4-11, doi: 10.2337/diaclin.32.1.4, indexed in Pubmed: 26246672.

3. Cai X, Yang W, Gao X, et al. The Association Between the Dosage of SGLT2 Inhibitor and Weight Reduction in Type 2 Diabetes Patients: A Meta-Analysis. Obesity (Silver Spring). 2018; 26(1): 70-80, doi: 10.1002/oby.22066, indexed in Pubmed: 29165885.

4. Thewjitcharoen Y, Yenseung N, Malidaeng A, et al. Effectiveness of long-term treatment with SGLT2 inhibitors: real-world evidence from a specialized diabetes center. Diabetol Metab Syndr. 2017; 9: 96, doi: 10.1186/s13098-017-0297-y, indexed in Pubmed: 29213337.

5. Ferrannini G, Hach T, Crowe S, et al. Energy Balance After Sodium-Glucose Cotransporter 2 Inhibition. Diabetes Care. 2015; 38(9): 1730-1735, doi: 10.2337/dc15-0355, indexed in Pubmed: 26180105. 